\title{
IMPLEMENTASI KEBIJAKAN TENTANG PERLINDUNGAN DAN PENGELOLAAN LINGKUNGAN HIDUP PADA PERTAMBANGAN INTAN RAKYAT KOTA BANJARBARU
}

\author{
Jumarianto \\ Fakultas Ilmu Administrasi Universitas Achmad Yani \\ E-mail : kelasjumarianto@gmail.com
}

\begin{abstract}
The purpose of this research is to find out how the implementation of Law of the Republic of Indonesia number 32 of 2009 concerning the protection and management of the environment for miners in the diamond mining of Sungai Tiung Village, as well as the role of the community and the government in implementing this law. The type of research used is descriptive qualitative. The results showed that the implementation of policies on Environmental Protection and Management in Diamond Mining in the Sungai Tiung Village, Banjarbaru City has been going well. however, activities to restore environmental functions and other methods that are in accordance with science and technology are not implemented. Based on the government's role, it is the provision of suggestions, opinions, suggestions, objections, and plaintiffs. Implemented by providing suggestions, appeals, warnings and complaints. Information and report delivery activities are carried out by providing information to Sungai Tiung Village through community leaders
\end{abstract}

Keywords : policy implementation,mining,environment, government

\section{PENDAHULUAN}

Setiap kerusakan lingkungan dan pencemaran lingkungan yang timbul pada suatu daerah atau wilayah tertentu yang diutarakan oleh sebagian masyarakat adalah semua bersumber dari pemerintah, padahal jika mampu menginstropeksi dalam diri maka semua saling keterkaitan. Pada saat ini wilayah Indonesia mengalami kerusakan lingkungan dengan ditandai adanya bencana dimana-mana yang dapat kita saksikan pada media masa elektronik maupun media sosial. Permasalahan lingkungan dewasa ini menjadi isu global dikalangan masyarakat dunia. Tidak terkecuali di Indonesia dan berbagai daerah diseluruh Indonesia. Kerusakan lingkungan Indonesia dari hari ke hari terasa semakin memprihatinkan. Saat alam rusak karena dihancurkan dan kehilangan sumber daya, maka itu merupakan tanda bahwa lingkungan mengalami kerusakan. Saat ini wilayah Indonesia diberbagai daerah mengalami berbagai akibat dari kerusakan alam tersebut yang berakibat pada kehidupan mahluk hidup. Sebagian wilayah Indonesia yang menghadapi bencana tersebut lebih banyak terjadi karena ulah manusia, dan baru-baru ini ada pula wilayah Indonesia yang mengalami bencana alam seperti tanah longsor, banjir akibat tidak seimbangnya lingkungan hidup yang seharusnya selalu dijaga agar tidak menimbulkan bencana.
Penyebab kerusakan alam dapat disebabkan oleh dua faktor yaitu akibat peristiwa alam dan akibat ulah manusia. Kerusakan yang diakibatkan oleh peristiwa alam adalah peristiwa yang terjadi secara alami oleh alam dengan terjadinya perubahan pada keadaan geografis setiap wilayah yang berakibat pada pergeseran keadaan suatu daerah, sedangkan kerusakan yang diakibatkan oleh ulah manusia adalah kerusakan yang timbul baik disengaja maupun tidak disengaja oleh manusia dalam memperlakukan alam yang tidak sesuai dengan semestinya, kerusakan yang disebabkan oleh manusia ini dampaknnya lebih besar dibandingkan dengan kerusakan akibat bencana alam. Jika manusia memiliki kesadaran dalam mengelola sumber daya yang ada dengan baik maka para generasi mendatang baik untuk kita ataupun untuk anak cucu kita tidak akan merasakan dampak yang tidak semestinya, tetapi akan merasakan dampak dan hasil yang baik dari penjagaan lingkungan. Faktor lain yang menyebabkan rusaknya lingkungan hidup yang dapat dikategorikan sebagai ulah manusia adalah salah satunya dari proses pertambangan. Pertambangan adalah rangkaian kegiatan dalam rangka upaya pencarian, penambangan (penggalian), pengolahan, pemanfaatan, dan penjualan bahan galian (mineral, batubara, panas bumi, migas) dengan mengeksploitasi lahan yang akan dijadikan area pertambangan. Lebih rinci menurut UndangUndang Republik Indonesia Nomor 4 Tahun 2009 pasal 1 ayat 6 yaitu menjelaskan : 
"Usaha Pertambangan adalah kegiatan dalam rangka pengusahaan mineral atau batubara yang meliputi tahapan kegiatan penyelidikan umum, eksplorasi, studi kelayakan, konstruksi penambangan, pengelolaan dan pemurnian, pngangkutan dan penjualan, serta pasca tambang".

Pertambangan terbagi menjadi dua pertambangan rakyat dan pertambangan resmi. Petambangan resmi adalah pertambangan yang dilakukan oleh perusahaan-perusahaan yang memiliki izin resmi dari pemerintah dan memiliki payung hukum yang jelas untuk mengeksploitasi dengan mengelola lahan yang ditambang untuk kepentingan perusahaannya. Sedangkan pertambangan rakyat adalah pertambangan yang dikelola dan dilakukan oleh sekelompok orang (rakyat sekitar pertambangan maupun para pendatang) dengan bekerjasama ataupun perorangan dalam mengelola lahan yang diinginkan untuk ditambang baik ada izin maupun tanpa ada izin dari pemerintah. Lebih jelas mengenai pertambangan rakyat dalam Undang-Undang Republik Indonesia No.11 Tahun 1967 pasal 2 huruf $\mathrm{n}$ sebagaimana dikutip As'ad (2005) yaitu :

"Pertambangan Rakyat adalah suatu usaha pertambangan bahan-bahan galian dari semua golongan $a, b$, dan $c$ seperti yang dimaksud dalam pasal 3 ayat 1 yang dilakukan oleh rakyat setempat secara kecil-kecilan atau secara gotong royong dengan alat-alat sederhana untuk pencarian sendiri".

Salah satu pertambangan rakyat yang ada di Indonesia adalah pertambangan intan rakyat yang berada di daerah Kalimantan Selatan tepatnya di Kota Banjarbaru Kecamatan Cempaka Kelurahan Sungai Tiung. Aktivitas yang dilakukan oleh penduduk Cempaka dalam hal pertambangan adalah menambang batu, pasir, intan, emas, dan batubara (dalam As'ad:2005). Pada Kelurahan Sungai Tiung umumnya masyarakatnya memilih mata pencaharian dengan menjadi penambang intan. Pertambangan intan tersebut dikelola oleh sekelompok orang yang bekerja sama dengan pemilik mesin, dan seorang pemilik tanah. Tanah tersebut dikelola oleh para sekelompok penambang tanpa didasari dengan prosedur hukum yang jelas, baik dasar hukum pertambangan atau hukum pertambangan rakyat. Para penambang yang melakukan pertambangan dahulu kala hanya menggunakan sarana dan alat sederhana kini dengan dengan seiring kemajuan zaman, para penambang mulai menggunakan teknologi dan mesin-mesin guna menggali lahan pertambangan.
Disisi lain para penambang sedang mempertaruhkan hidupnya guna mencari penghidupan bagi keluarganya, masyarakat yang tidak melakukan aktifitas pertambangan intan rakyat tersebut kian hari makin resah terhadap kerusakan lingkungan yang terjadi di wilayahnya. Keresahan tersebut timbul dari kegelisahan masyarakat sekitar akan bahaya dampak lingkungan yang ditimbulkan akibat dari kerusakan lingkungan pertambangan intan rakyat Kelurahan Sungai Tiung tersebut. Kerusakan lingkungan alam dari penambangan akan berimbas pada kehidupan masyarakat terutama pada keberlangsungan kehidupan manusia di wilayah sekitar pertambangan intan rakyat tersebut. Masyarakat bergantung pada lingkungan tempat mereka hidup dan tinggal untuk kehidupan sehari-harinya.

Dampak yang timbul tersebut perlu diperhatikan karena akan berdampak pada masyarakat sekarang maupun generasi mendatang guna keberlangsungan kehidupan yang baik pada masa akan datang. Perlunya sebuah sosialisasi, pengawasan, dan pemantauan dari aktivitas pertambangan intan tersebut seharusnya dilakukan agar mampu menjaga dan mengendalikan lingkungan agar tetap lestari, tetapi pada kenyataannya kurangnya pengawasan terhadap kegiatan dan aktivitas pertambangan tersebut terjadi pada pemerintah daerah setempat yaitu Kelurahan Sungai Tiung, dimana kurangnya pemantauan dan pengawasan serta sosialisasi tersebut mengakibatkan para masyarakat (penambang) melakukan kegiatannya terus-menerus tanpa henti dalam mengeksploitasi sumber daya alam tanpa memperhatikan lingkungan.

Dari keadaan permasalahan diatas perlunya sebuah kebijakan yang mengatur bagaimana seorang individu atau kelompok bersikap dan bertingkah laku. Kebijakan tersebut merupakan aturan yang bisa bersifat mengikat atau pun tidak mengikat tergantung pada wilayah di mana kebijakan tersebut ditetapkan. Pada penelitian ini, peneliti lebih menekankan pada kebijakan publik. Di mana kebijakan publik tersebut dibuat dan diputuskan oleh penjabat pemerintah untuk mengatur dan mengarahkan baik individu perorangan atau sekelompok masyarakat yang mencakup wilayah nasional ataupun lokal daerahnya masing-masing dan bersifat mengikat dan mengarahkan sesuai dengan tujuan dan program tertentu pada sebuah kebijakan publik. Pada dasarnya para masyarakat (para penambang) pertambangan intan rakyat sangat memerlukan sebuah kebijakan tersebut, agar dapat mengatur 
bagaimana aktivitas pertambangan itu berlangsung dengan menjaga pemanfaatan sumber daya alam dan lingkungan hidup tetap lestari. Bukan hanya sebuah kebijakan saja yang diperlukan bagi para penambang, selain setelah kebijakan tersebut ditetapkan harus ada implementasi yang nyata dari pembuatan sebuah aturan yang dapat mengatur seseorang atau pun kelompok. Implementasi merupakan sebuah tindakan atau kegiatan yang terarah berdasarkan tujuan dan program tertentu dari sebuah kebijakan yang dilaksanakan secara nyata pada kehidupan.

\section{TINJAUAN PUSTAKA}

\section{Electronic Government}

\section{Implementasi Kebijakan}

Implementasi merupakan tindakan-tindakan untuk mencapai tujuan yang telah digariskan dalam keputusan kebijakan. Tindakan tersebut dilakukan baik oleh individu, pejabat pemerintah ataupun swasta. Dunn mengistilahkannya implementasi secara lebih khusus, menyebutnya dengan istilah implementasi kebijakan dalam bukunya yang berjudul Analisis Kebijakan Publik. Menurutnya implementasi kebijakan (Policy Implementation) adalah pelaksanaan pengendalian aksi-aksi kebijakan didalam kurun waktu tertentu. Implementasi merupakan tindakan-tindakan untuk mencapai tujuan yang telah digariskan dalam keputusan kebijakan. Tindakan tersebut dilakukan baik oleh individu, pejabat pemerintah ataupun swasta.

Dunn mengistilahkannya implementasi secara lebih khusus, menyebutnya dengan istilah implementasi kebijakan dalam bukunya yang berjudul Analisis Kebijakan Publik. Menurutnya implementasi kebijakan (Policy Implementation) adalah pelaksanaan pengendalian aksi-aksi kebijakan didalam kurun waktu tertentu. Berkaitan dengan faktor yang mempengaruhi implementasi kebijakan suatu program, Subarsono dalam bukunya yang berjudul Analisis Kebijakan Publik (Konsep, Teori dan Aplikasi), mengutip pendapat G. Shabbir Cheema dan Dennis A. Rondinelli mengemukakan bahwa terdapat beberapa faktor yang mempengaruhi implementasi kebijakan program-program pemerintah yang bersifat desentralistis.

Berdasarkan pendapat dari G. Shabbir Cheema dan Dennis A. Rondinelli tersebut terdapat faktor yang menentukan keberhasilan suatu implementasi kebijakan yang diterapkan. Apabila kita ingin mengetahui kebijakan yang diterapkan, kegagalan atau keberhasilannya bisa diukur oleh faktor-faktor yang dapat mempengaruhi kebijakan.

\section{Undang-Undang RI Nomor 32 Tahun 2009 Tentang Perlindungan dan Pengelolaan Lingkungan Hidup}

Dalam hal ini Pemerintah Republik Indonesia selaku pemerintah dan penjabat yang memberikan kewenangan dan perlindungan bagi seluruh masyarakat Republik Indonesia dalam melaksanakan kegiatan usahanya, dalam berbagai bidang dengan memperhatikan aspek lingkungan dan kelestarian alam sebagai dasar dari suatu pembangunan yang berwawasan lingkungan. Pemerintah Republik Indonesia memberikan acuan kepada pemerintah daerah untuk melaksanakan perlindungan dan pengelolaan lingkungan hidup, agar terjaminnya keterlaksanaan kegiatan yang dilaksanakan oleh masyarakat dalam pemanfaatan sumber daya alam dan pelestarian lingkungan. Oleh karena itu Pemerintah Republik Indonesia mengeluarkan suatu kebijakan berupa UndangUndang Republik Indonesia nomor 32 tahun 2009 tentang Perlindungan dan Pengelolaan Lingkungan Hidup.

\section{Kerusakan Lingkungan}

Menurut K.E.S Manik (2016:32) Perusakan lingkungan adalah tindakan yang menimbulkan perubahan langsung atau tidak langsung terhadap sifat-sifat fisik dan/atau hayati lingkungan, yang mengakibatkan lingkungan itu kurang atau tidak berfungsi lagi dalam menunjang pembangunan yang berkesinambungan. Kerusakan lingkungan hidup akan mengakibatkan suatu perubahan sifatsifat dan unsur-unsur lingkungan yang berakibat peran dan arti penting lingkungan hidup bagi kehidupan menjadi terganggu, bahkan tidak berfungsi lagi. Sehingga dapat disimpulkan kerusakan lingkungan atau kerusakan lingkungan hidup adalah tindakan yang dilakukan pada lingkungan hidup dan alam yang mengakibatkan kerusakan berupa perubahan mutu lingkungan hidup, serta menurunya fungsi lingkungan hidup baik secara langsung maupun secara tidak langsung berdampak pada kelangsungan mahluk hidup sekitarnya.

\section{Faktor Kerusakan Lingkungan}

Faktor Kerusakan Lingkungan merupakan penyebab dari mana asal kerusakan linkungan tersebut. Penyebab Kerusakan Lingkungan ada beberapa hal menurut Otto Soemarwoto (2003:2122). 
a. Pertama, antara citra lingkungan dengan keadaan lingkungan yang nyata selalu terdapat perbedaan. Perbedaan ini menyebabkan ketidaksempurnaan dalam pengelolaan lingkungan. Hal ini terutama terdapat dalam hal terjadi perubahan lingkungan yang tidak terekam oleh masyarakat, sehingga citra lingkungan tetap tidak berubah dalam kondisi lingkungan yang berubah.

b. Kedua, sering tanda kerusakan lingkungan tidak terekam oleh masyarakat karena masyarakat terbiasa dan menyesuaikan diri dengan penurunan kualitas lingkungan yang terjadi secara bertahap dalam jangka waktu yang panjang. Kerusakan itu baru disadari setelah terlambat dan bersifat tidak terbalikkan lagi.

c. Ketiga, manusia tidak selalu bertindak rasional sesuai dengan citra lingkungan yang mereka miliki, terutama jika manusia harus memenuhi kebutuhan jangka pendeknya sehari-hari, seperti pangan, rumput untuk ternak, dan kayu bakar.

d. Keempat, sementara faktor-faktor di atas sifatnya tidak sengaja karena tidak adanya kesadaran akan bahaya, kini terdapat pula kerusakan lingkungn karena ketamakan.

Faktor lain kerusakan lingkungan hidup kita dijelaskan oleh Otto Soemarwoto (2001:72-83). Menurutnya manusia merupakan sumber penting kerusakan lingkungn hidup kita.

1) Kependudukan, Setiap orang mempengaruhi lingkungan hidupnya. Makin besar jumlah orangnya, makin besar pula potensi dampaknya. Penelitian di dalam dan di luar negeri menunjukan bahwa hal ini terjadi juga pada masyarakat tardisional. Dengan pertumbuhan jumlah penduduknya mereka melakukan eksploitasi-lebih pada sumber daya alamnya sehingga terjadi kerusakan.

2) Sikap terhadap lingkungan hidup, prinsip pembangunan berwawasan lingkungan ialah memasukan faktor lingkungan hidup dalan perencanaan dan pelaksanaan pembangunan. Dengan demikian dampak negative dari kerusakan lingkungan hidup dapat dibatasi sampai pada batas minimum. Pembangunan tersebut bersifat ramah lingkungan. Tetapi walaupun pembangunan ramah lingkungan telah kita setujui bersama, pelaksanaannya menghadapi kendala besar. Para birokrat, pakar ekonomi, usahawan, bahkan juga pakar lingkungan hidup berpegangan pada tesis bahwa melindungi lingkungan hidup memerlukan biaya, baik biaya rill maupun biaya kesempatan (opportunity cost). Selain itu terjadinya kontroversi antara lingkungan hidup dan pembangunan, di mana anggapan harus memilih pembangunan dulu atau lingkungan hidup dulu.

3) Ketidaksadaran lingkungan hidup, Sebenarnya pengetahuan masyarakat tentang lingkungan hidup cukup luas. Tetapi pengetahuan itu tidak menjelma menjadi kesadaran lingkungan hidup yang menumbuhkan komitmen ramah lingkungan hidup. Tidak tumbuhnya sikap dan kelakuan ramah lingkungan hidup dipengaruhi oleh beberapa faktor yaitu:

a) Pertimbangan ekonomi, pertimbangan ekonomi sangat dipengaruhi oleh pandangan bahwa ramah lingkungan adalah mahal.

b) Kebudayaan, kebudayaan mempengaruhi sikap manusia terhadap lingkungan hidupnya. Kita mempunyai ajaran untuk hidup serasi dengan sesame manusia, lingkungan hidup, dan Tuhan.

c) Penegakan hukum yang lemah, di negeri ini penegakan hukum sangat lemah, peraturan banyak dilanggar.

\section{Penanggulangan Pencemaran dan/atau Kerusakan Lingkungan Hidup}

Penanggulangan adalah upaya yang dilaksanakan untuk mencegah, menghadapi, atau mengatasi suatu keandaan mencakup sebuah tindakan untuk mencari solusi terhadap suatu masalah. Penanggulangan adalah suatu istilah untuk menyebutkan cara mengatasi, memperbaiki, dan membenahi suatu peristiwa / kejadian yang terjadi. Dalam kaitannya dengan pencemaran dan kerusakan lingkungan hidup, penanggulangan adalah upaya atau cara yang dilaksanakan untuk memperbaiki, menghadapi, dan mengatasi pencemaran atau kerusakan lingkungan yang terjadi di suatu wilayah, guna mencari solusi yang terbaik untuk mengatasi kerusakan lingkungan tersebut. Dalam Undang-Undang Republik Indonesia Nomor 32 tahun 2009 Pasal 53 ayat 2, penanggulangan pencemaran dan kerusakan lingkungan dapat dilaksanakan dengan pemberian informasi peringatan pencemaran dan/atau kerusakan lingkungan hidup kepada masyarakat, pengisolasian pencemaran dan/ atau kerusakan lingkungan hidup, penghentian sumber pencemaran dan/ atau kerusakan lingkungan hidup, dan cara lain yang sesuai dengan perkembangan ilmu pengetahuan dan teknologi.

\section{Pertambangan Rakyat}

Pengertian pertambangan rakyat terdapat pada Peraturan Mentri Pertambangan dan Energi

39 | Jumarianto | Implementasi kebijakan....... 
Nomor 01 P/201/M.PE/1986 tentang Pendoman Pengelolaan Pertambangan Rakyat Bahan Galian Strategis dan Vital (Golongan A dan B) (dalam As'ad:2005), adalah usaha pertambangan bahan galian strategis (golongan a) dan vital (golongan b) yang dilakukan oleh rakyat setempat yang bertempat tinggal di daerah bersangkutan untuk penghidupan mereka sendiri sehari-hari yang diusahakan secara sederhana.

Menurut As'ad (2005:2) dapat dikemukakan beberapa unsur pertambangan rakyat, yaitu :

a. Usaha pertambangan.

b. Bahan galian yang diusahakan meliputi galian strategis, vital, dan golongan c.

c. Dilakukan oleh rakyat.

d. Domisili di area tambang rakyat.

e. Untuk penghidupan sehari-hari.

f. Diusahakan dengan cara sederhana.

Pertambangan Rakyat yaitu usaha pertambangan bahan galian yang dilakukan oleh rakyat setempat secara kecil-kecilan atau gotong royong dengan peralatan sederhana untuk mata pencaharian sendiri.

Rahmi (1995) menggolongkan bahan-bahan galian tambang adalah sebagai berikut :

1) Galian A, merupakan bahan galian strategis, yaitu untuk perekonomian Negara serta pertahanan dan keamanan Negara. Contoh : minyak bumi, batubara, unarium, dan lain-lain.

2) Galian $B$, merupakan bahan galian vital, yaitu dapat menjamin hajad hidup orang banyak. Contoh : besi, tembaga, emas, perak, dan lainlain.

3) Galian C, bukan merupakan bahan galian strategis ataupun vital, karena sifatnya tidak langsung memerlukan pasaran yang bersifat internasional. Misalnya: marmer, batu kapur, tanah liat, pasir, yang sepanjang tidak mengandung unsur mineral.

\section{METODE PENELITIAN}

Penelitian menggunakan pendekatan kualitatif dengan metode analisis deskriptif. Lokasi penelitian merupakan tujuan obyek tempat pelaksanaan penelitian. Penelitian ini dilaksanakan pada daerah Kelurahan Sungai Tiung, Kecamatan Cempaka, Kota Banjarbaru, Propinsi Kalimantan Selatan.

\section{HASIL DAN PEMBAHASAN}

Sungai Tiung merupakan sebuah kelurahan di Kecamatan Cempaka, Kota Banjarbaru, Propinsi Kalimantan Selatan, Indonesia. Wilayah Sungai Tiung dahulu merupakan wilayah bagian dari
Kabupaten Banjar, setelah diadakannya pemekaran wilayah Kota Banjarbaru pada tahun 1999, dimana sebelum menyandang status sebagai Kotamadya, Banjarbaru lebih dulu menyandang status sebagai Kota Administratif pada tahun 1968. Sehingga dari tahun 1999 Kota Banjarbaru resmi berdiri sendiri sebagai Kotamadya, yaitu Kota Banjarbaru. Berikut merupakan profil Kelurahan Sungai Tiung.

\section{Implementasi Kebijakan}

Berdasarkan hasil penelitian, para penambang bertempat tinggal di Sungai Tiung sejak lahir, sehingga mereka melakukan pekerjaan sebagai penambang (pendulang) melanjutkan tradisi turun temurun orang tuanya yang merupakan masyarakat Kelurahan Sungai Tiung. Didasarkan dari tradisi tersebutlah sehingga pendidikan para pendulang tersebut sangat rendah. Secara umum para pendulang yang melakukan penambangan intan rakyat di Kelurahan Sungai Tiung berpendidikan tamat Sekolah Dasar (SD). Rata-rata responden tidak menamatkan sekolah dasarnya. Itu terjadi karena pada dahulu pencarian kegiatan pertambangan intan rakyat tersebut masih ramai dan hasil intan masih melimpah, hasil yang didapat pun dalam kegiatan pendulangan tersebut sangat memuaskan. Sehingga membuat masyarakat beranggapan bahwa pendidikan tidak terlalu penting karena hasil yang mereka dapat sangat memuaskan. Kegiatan penambang (pendulang) intan yang mereka tekuni tersebut benar merupakan hasil dari budaya tradisi turun temurun dari nenek moyangnya. Sehingga dari hasil turun temurun tersebutlah maka para pendulang (penambang) intan tersebut merupakan sebagian besar berasal dari daerah Sungai Tiung itu sendiri. Lama bekerja sebagai penambang.

\section{1) Alasan bertahan sebagai penambang}

Alasan para penambang tetap menekuni kegiatan pendulangan intan tersebut dengan rentang waktu yang cukup lama hingga saat ini secara umum adalah mereka beralasan bahwa tidak ada pekerjaan lain selain menambang (mendulang) intan. Berikut wawancara pada salah satu penambang yaitu, Fajarani penambang daerah Ujung Murung menerangkan bahwa :

"Kalau kerja dilain, tidak

cukup untuk persyaratannya.

Persyaratan untuk kerja di tempat

lain itu tidak ada".

Selain dari segi persyaratan faktor lain yaitu dari segi penghasilan seorang penambang bedasarkan keterangan wawancara salah satu penambang daerah Pumpung yaitu, M. Taufik Jumarianto | Implementasi kebijakan....... 40 
dengan menerangkan bahwa :

"Hasilnya menggiurkan, artinya hasilnya tersebut bisa membuat kaya. Soalnya dalam sekali dapat intan itu bisa untuk beli motor dan mobil. Jadi, dibandingkan dengan pekerjaan lain tidak ada bandingannya, karena para pendulang tersebut kalo sudah dapat intan pasti kaya".

Berdasarkan hasil wawancara tersebut dapat dijelaskan bahwa, selain faktor tidak dapat bekerja dilain lagi. Faktor lain pun seperti butuh persyaratan yang mencukupi untuk bekerja di tempat lain, sedangkan dari tingkat pendidikan mereka saja sudah sangat kurang. Selain dari tingkat pendidikan yang kurang dan kesulitan untuk melamar pekerjaan di tempat lain. Faktor penghasilan pun menjadikan alasan yang sangat kuat. Penghasilan pada pekerjaan lain tidak cukup memuaskan dengan hasil yang didapat ketika para pendulang (penambang) dapat menghasilkan atau menemukan intan. Sehingga jelas bahwa pekerjaan sebagai penambang (pendulang) intan tersebut tidak dapat digantikan ataupun ditinggalkan oleh para penambangnya untuk beralih pada pekerjaan lain.

\section{2) Pengetahuan penambang}

Berdasarkan wawancara dapat dijelaskan bahwa ketika peneliti menanyakan perihal menurut pribadi para penambang tersebut tentang lingkungan yang baik, para penambang tersebut banyak terdiam maupun banyak yang salah mengartikan tentang maksud dari lingkungan yang baik tersebut. Sehingga hal tersebut didasari dari tingkat pendidikan para penambang sendiri yang masih rendah. Selain pengetahuan tentang lingkungan dan lingkunga hidup, para penambang pun menyadari bahwa kegiatan dan aktivitas pekerjaannya tersebut dapat merusak lingkungan. Berikut hasil wawancara dengan penambang Ujung Murung, yaitu bapak Abdul Qodir menerangkan bahwa :

"Menyadari bahwa kegiatannya
tersebut dapat merusak
lingkungan, tetapi istilahnya itu
sudah merupakan pekerjaan
sehari-hari. Sehingga untuk
disesali itu tidak bisa lagi. Artinya
sudah tidak ada pekerjaan selain
itu”.

Selain itu keterangan dari para pendulang lainnya lebih menegaskan lagi dari M. Taufik penambang di daerah Pumpung, menerangkan bahwa :

\begin{abstract}
"Menyadari bahwa kegiatannya tersebut merusak lingkungan, karena hidup sudah di kampung, untuk bekerja di tempat lain memerlukan ijazah dan pengalaman. Jadi di sini kan memang sudah kampung yang kaya akan hasil alam yaitu berupa intan, emas, dan hasil tambang. Jadi, mengapa tidak dimanfaatkan sepenuhnya hasil alam itu, kan saya dan penambang lainnya juga merupakan orang asli kampung sini."
\end{abstract}

Berdasarkan hasil wawancara tersebut dapat dijelaskan bahwa dibalik kekurangannya mengetahui tentang lingkungan ataupun lingkungan hidup yang baik itu seperti apa, mereka (penambang/pendulang) secara keseluruhan masih memiliki kesadaran bahwa kegiatan yang mereka lakukan tersebut sangat jelas dapat merusak lingkungan. Tetapi kesdaran tersebut tidak diimbangi dengan pola perilaku mereka untuk meninggalkan kegiatan dan aktivitas penambangan tersebut yang merusak lingkungan, karena mereka beralasan bahwa tidak ada pekerjaan lain selain dari melakukan penambangan intan rakyat di Kelurahan Sungai Tiung.

3) Aktivitas dan kegiatan pertambangan intan rakyaT. Berikut proses pertambangan intan rakyat di Kelurahan Sungai Tiung adalah :

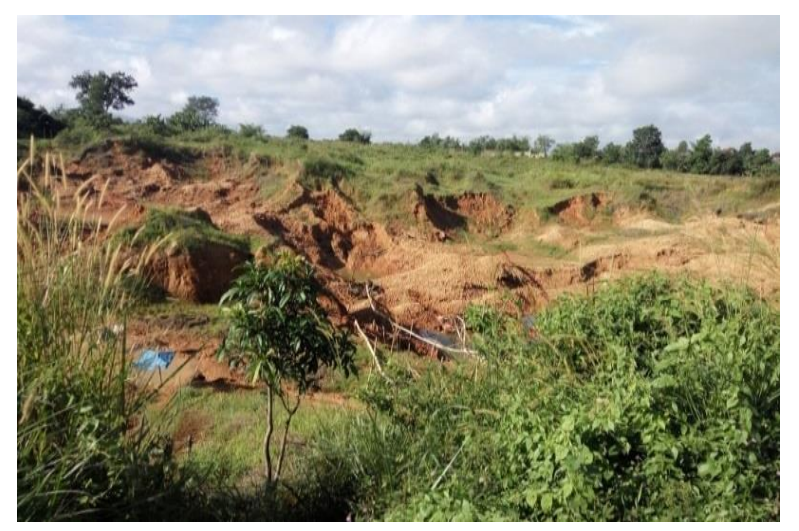

Gambar 1 : Lokasi penggalian pertambangan intan.

Pada gambar 1 tersebut menggambarkan proses awal, yaitu lokasi yang akan dilakukannya penggalian lubang untuk proses pertama dalam pertambangan intan rakyat di Kelurahan Sungai Tiung.

Proses selanjutnya adalah proses pengikisan tanah dari tebing-tebing pada lubang area 
pertambangan menggunakan alat linggis dan cangkul, proses pengikisan tersebut dilakukan dengan penggalian beberapa lapisan tanah yang paling atas hingga mencapai lapisan tanah yang paling bawah yang mengandung intan. Hasil dari pengikisan tersebut tanahnya berbentuk gumpalangumpalan. Kemudian tanah-tanah tersebut dicampur menjadi satu diaduk dengan cara disemprot menggunakan mesin semprot air. Pencampuran dan pengadukan tersebut dilakukan agar gumpalan-gumpalan tersebut hancur menjadi halus dan mudah disedot. Setelah dilakukan pengadukan supaya tanah-tanah tersebut menjadi halus dan lembut, maka dilakukan penyedotan. Penyedotan tersebut dilakukan menggunakan mesin dan dialirkan melalui pipa-pipa yang telah terpasang dan tersusun rapi menuju panggungan sesuai pada gambar 4 .

Pada saat proses penyedotan berlangsung, bahan dan material penggalian tersebut diadakan sebuah pengawasan/penjagaan. Tahap penjagaan dan pengawasan tersebut dilakukan dari awal proses penyedotan berlangsung. Tetapi pada tahap awal tersebut proses pengawasan dan penjagaan dilakukan secara biasa, agar air yang mengalir melalui pipa tersebut tidak mengenai penambangan yang lain. Proses penjagaan dan pengawasan material dilakukan sangat ekstra ketat oleh para penambang ketika mencapai lapisan tanah yang mengandung intan, hal itu dilakukan agar intan tidak ikut larut dan terbawa oleh material-material yang lain. Setelah selesai aktivitas penyedotan material tanah tersebut secara keseluruhan melalui pipa-pipa yang diarahkan menuju panggungan. Pada saat dipanggungan material-material yang tidak mengandung intan dan yang mengandung intan tersebut akan terseleksi secara sendirinya dengan alat pemisah dalam panggungan tersebut. Saat material yang tidak mengandung intan keluar dari penyaringan tersebut, maka akan dibiarkan saja meluncur melalui mesin panggungan menuju aliran-aliran sisa-sisa penambangan.

Setelah dilakukannya pemisahan antara material yang mengandung intan dan yang tidak mengandung intan dimesin panggungan, maka material yang mengandung intan tersebut akan keluar melalui bagian depan panggungan. Setelah keluar lapisan yang mengandung intan tersebut, maka para penambang melakukan kegiatan penjagaan ekstra. Kegiatan penjagaan ekstra tersebut dilakukan dengan membersihkan materialmaterial yang mengandung intan. Pembersihan tersebut dilakukan dengan adanya penyekatan (pemberian sekat) pada peluncuran materialmaterial yang mengandung intan agar menjadi tambah bersih lagi. Kegiatan tersebut dilakukan dengan menyemprotkan air pada peluncuran yang berisi material-material yang mengandung intan. Hal tersebut dilakukan agar material yang mengandung intan tidak ikut terbuang. Ketika tanah/material yang mengandung intan tersebut selesai disemprot dan dibersihkan, maka selesailah proses seleksi material-material yang mengandung intan.

4) Limbah hasil pertambangan intan rakyat

Setelah usainya segala proses penggalian hingga proses pelenggangan pertambangan intan rakyat tersebut, maka akan menghasilkan bahan sisa kegiatan tersebut yang disebut limbah. Limbah adalah bahan sisa yang dapat digunakan kembali atau yang tidak dapat digunakan kembali, yang berasal dari sisa aktivitas atau kegiatan. Sehingga limbah sisa pertambangan rakyat adalah bahan sisa hasil proses pertambangan rakyat baik yang dapat dikelola kembali maupun yang tidak dapat dikelola kembali. Berikut hasil wawancara dengan penambang daerah Pumpung, yaitu M. Taufik menerangkan bahwa :

"Sisa-sisa material pendulangan yang tidak bisa dipakai lagi itu seperti gundukan batu koral (batu koral besarbesar) dan tanah pasir yang tidak bisa dijual. Kalau batu koral yang kecil masih bisa dijual sama pasirnya. Sehingga kalau gundukan yang tidak bisa dijual itu sampai nanti akan tetap jadi gundukan seperti itu. Tetapi kalau gundukan pasir dan batu koral yang bisa dijual diangkut jika ada jalan mobilnya, bila tidak ada jalan mobilnya ya jadi gundukan tanah saja".

Berdasarkan hasil wawancara tersebut dapat dijelaskan bahwa limbah atau bahan sisa kegiatan dan aktivitas pada pertambangan intan rakyat di Kelurahan Sungai Tiung adalah pasir, batu koral, lumpur, lubang sisa penggalian, dan tumpukan pasir dan batu koral yang tidak dapat terjual. Limbah-limbah tersebut terbagi menjadi 2 kategori yaitu limbah yang dapat dijual kembali dan limbah yang tidak dapat dikelola kembali. Limbah yang dapat dijual dan dikelola kembali adalah batu koral, batu koral tersebut dapat dijadikan cindera mata khas cempaka yaitu batu akik, selain itu dapat pula dijadikan bahan bangunan. Kemudian pasir, tidak berbeda jauh dengan batu koral, maka pasir juga dapat dijual dan dijadikan sebagai bahan bangunan. Karena pasir merupakan bahan utama pembuatan

Jumarianto | Implementasi kebijakan....... | 42 
sebuah bangunan. Limbah yang dapat dijual tersebut dapat terjual jika ada jalan mobil untuk mengangkut material yang dapat dijual tersebut. Jika tidak ada jalan yang dapat memuat mobil pengangkut untuk mengangkut material tersebut maka pasir dan batu koral tidak dapat dijula dan hanya akan menjadi tumpukan pasir dan batu koral. Selain bahan limbah yang dapat dikelola kembali, terdapat pula bahan limbah yang tidak dapat dikelola kembali yaitu lumpur dan lubang sisa galian. Lumpur tidak dapat dikelola kembali karena tidak dapat mendatangkan manfaat apapun dan hanya akan menjadikan limbah. Sedangkan lubang sisa galian proses pertambangan akan terus tetap menjadi lubang jika tidak ditutup kembali dan akan menjadikan rusaknya sebuah lingkungan.

\section{KESIMPULAN}

Berdasarkan hasil penelitian dan pembahasan, Adapun kesimpulan dalam peenelitian ini adalah :

1. Implementasi kebijakan Tentang Perlindungan dan Pengelolaan Lingkungan Hidup Pada Pertambangan Intan Rakyat di Kelurahan Sungai Tiung Kota Banjarbaru sudah berjalan dengan baik. kegiatan pemulihan fungsi lingkungan dan metode lain yang sesuai dengan ilmu pengetahuan dan teknologi. Kegiatan pemulian yang dilakukan dengan penutupan kembali lubang bekas galian tambang, dengan memasukan dan mengalirkan limbah-limbah sisa pendulangan tersebut ke lubang bekas galian tambang yang terdahulu sehingga dapat tertutup secara alami dengan sendirinya. Penanggulangan pencemaran dan kerusakan lingkungan hidup dilakukan dengan kegiatan pertama, pemberian informasi peringatan pencemaran dan kerusakan lingkungan hidup kepada masyarakat, pemberian informasi kepada pemilik lahan yang akan dialiri dan dilewati limbah dan pemberian informasi kepada masyarakat sebelum dilaksanakannya kegiatan penggalian pertambangan. Pengisolasian pencemaran dan kerusakan lingkungan hidup dilakukan dengan membuat jalan khusus untuk aliran limbah, membuat sekat (dinding) pada pinggiran sawah yang akan terlewati limbah, dan diadakannya penjagaan oleh para penambang pada saat proses pembuangan limbah dialirkan. Kegiatan lain yang bertanggung jawab adalah kegiatan ganti lahan yang terkena limbah pendulangan sebesar 2,5\% dari hasil penjualan intan. Sehingga hal tersebut cukup baik terlaksana. Sehingga implementasi Undang-Undang Republik Indonesia nomor 32 tahun 2009 tentang perlindungan dan pengelolaan lingkungan hidup di Kelurahan Sungai Tiung Kota Banjarbaru sudah berjalan dengan baik.

2. Dampak yang mempengaruhi Implementasi kebijakan tentang perlindungan dan pengelolaan lingkungan hidup pada pertambangan intan rakyat di kelurahan Sungai Tiung Kota Banjarbaru adalah Persawahan yang sudah tidak ada lagi akibat rusak. Wilayah persawahan tersebut rusak akibat dialih fungsikannya menjadi lokasi pertambangan intan rakyat, Lubang bekas galian tambang, baik lubang yang kering maupun yang terisi air berbentuk danau. Lubang tersebut dibiarkan terbuka melebar tanpa ditutup kembali, Sungai menjadi rusak, terjadinya pendangkalan sungai dan air sungai menjadi berwarna coklat dan keruh, akibat dari limbah sisa pertambangan intan, Banjir, akibat pendangkalan sungai dan perubahan arah arus sungai akibat limbah. Sehingga air meluap menuju perumahan penduduk disekitar sungai dan sekitar pertambangan intan Pencemaran air bersih, yang menyebabkan tercemarnya sumber air bersih warga akibat aktivitas dan kegiatan pertambangan intan rakyat. Sehingga hal ini yang perlu dijadikan evaluasi kembali bagi pemerintah dalam mengimplementasikan kebijakan tentang Tentang Perlindungan dan Pengelolaan Lingkungan Hidup Pada Pertambangan Intan Rakyat di Kelurahan Sungai Tiung Kota Banjarbaru.

\section{REFERENSI}

Abdul Wahab, Solichin, 1997. Analisis Kebijaksanaan dan Formulasi ke Implementasi Kebijaksanaan Negara, Bumi Aksara, Jakarta.

, __ 2007. Kebijakan dan Permasalahannya, CV Indah Sentosa, Semarang.

Agoes Soegianto, 2005. Ilmu Lingkungan Sarana Menuju Masyarakat Berkelanjutan, Airlangga University Press, Surabaya.

As'ad, 2005. Pengelolaan Lingkungan Hidup Pada Pertambangan Rakyat Studi Kasus Penambangan Intan Rakyat Di Kecamatan Cempaka Kota Banjarbaru Propinsi Kalimantan Selatan, Universitas Ponorogo, Jurnal Online,

A.Tresna Sastrawijaya, 2000. Pencemaran Lingkungan, Cetakan ke 2, Rineka Cipta, Jakarta.

Ebta Setiawan. "Arti Kata Pemulihan." Kamus Besar Bahasa Indonesia kbbi.web.id. 20

43 | Jumarianto | Implementasi kebijakan....... 
April 2017. <http://kbbi.web.id/pulih

Eddy Soetrisno, 2010. Kamus Populer Bahasa Indonesia, Edisi Revisi, Sinergi Pustaka Indonesia, Bandung.

H. Hadari Nawawi, 1983. Metode Penelitian Bidang Sosial, Gadjah Mada University Press, Yogyakarta.

Islamy, 2009. Pengantar Kebijakan Publik dan Administrasi Publik, CV Indah Sentosa, Medan.

Iwan, 2013. Dampak Aktivitas Penambangan Pasir di Desa Ayula Tilango Kecamatan Bulango Selatan Kabupaten Bone Bolango, F.MIPA Universitas Negeri Gorontalo, Gorontalo, Jurnal Online,

K. E. S. Manik, 2016. Pengelolaan Lingkungan Hidup, Edisi ke 1, Prenada Media Group, Jakarta.

Kukuh S. Dewobroto, dkk, 1995. Kamus Konservasi Sumber Daya Alam, Edisi ke 2, PT Rineka Cipta, Jakarta.

Laila Azkia, 2012. Pemanfaatan Moment Produktif Dalam Tambang Rakyat Sebuah Aplikasi Soft Systems Metdhodology (SSM), Universitas Indonesia, Jakarta, Jurnal Online,

Lihawa, Fitryane, 2011. Konservasi dan Reklamasi Lahan, Reviva Cendekia, Gorontalo.

Otto Soemarwoto, 2003. Analisis Dampak Lingkungan, Cetakan ke 10, Gadjah mada University Press, Yogyakarta.

Otto Soemarwoto, 2003. Analisis Dampak Lingkungan, Cetakan ke 10, Gadjah mada University Press, Yogyakarta.

Pemerintah Republik Indonesia, Undang-Undang Republik Indonesia Nomor 9 tahun 2009, tentang Pengelolaan Limbah Bahan Berbahaya dan Beracun.

Pemerintah Republik Indonesia, Undang-Undang Republik Indonesia Nomor 32 tahun 2009, tentang Perlindungan dan Pengelolaan Lingkungan Hidup. 